\title{
Detection and quantification of Leptographium wageneri, the cause of black-stain root disease, from bark beetles (Coleoptera: Scolytidae) in Northern California using regular and real-time PCR
}

\author{
Wolfgang Schweigkofler, William J. Otrosina, Sheri L. Smith, Daniel R. Cluck, \\ Kevin Maeda, Kabir G. Peay, and Matteo Garbelotto
}

\begin{abstract}
Black-stain root disease is a threat to conifer forests in western North America. The disease is caused by the ophiostomatoid fungus Leptographium wageneri (W.B. Kendr.) M.J. Wingf., which is associated with a number of bark beetle (Coleoptera: Scolytidae) and weevil species (Coleoptera: Curculionidae). We developed a polymerase chain reaction test to identify and quantify fungal DNA directly from insects. Leptographium wageneri DNA was detected on 142 of 384 bark beetle samples (37\%) collected in Lassen National Forest, in northeastern California, during the years 2001 and 2002. Hylastes macer (LeConte) was the bark beetle species from which Leptographium DNA was amplified most regularly (2001: 63.4\%, 2002: 75.0\% of samples). Lower insect-fungus association rates were found for Hylurgops porosus (LeConte), Hylurgops subcostulatus (Mannerheim), Hylastes gracilis (LeConte), Hylastes longicollis (Swaine), Dendroctonus valens (LeConte), and Ips pini (Say). The spore load per beetle ranged from 0 to over $1 \times 10^{5}$ spores, with only a few beetles carrying more than $1 \times 10^{3}$ spores. The technique permits the processing of a large number of samples synchronously, as required for epidemiological studies, to study infection rates in bark beetle populations and to identify potential insect vectors.

Résumé : Le noircissement des racines est une maladie qui menace les forêts de l'ouest de l'Amérique du Nord. La maladie est causée par Leptographium wageneri (W.B. Kendr.) M.J. Wingf., un champignon de la famille des Ophiostomataceae qui est associé à plusieurs espèces de scolytes (Coléoptères : Scolytidae) et de charançons (Coléoptères : Curculionidae). Nous avons mis au point un test de réaction en chaîne de la polymérase pour identifier et quantifier l'ADN fongique directement à partir des insectes. L'ADN de L. wageneri a été détecté sur 142 des 384 (37\%) échantillons de scolytes collectés dans la forêt nationale de Lassen, dans le nord-est de la Californie, au cours des années 2001 et 2002. Hylastes macer (LeConte) était l'espèce de scolyte à partir duquel l'ADN de Leptographium a été le plus régulièrement amplifié (2001:63,4\%, $2002: 75,0 \%$ des échantillons). Des taux d'association plus faibles ont été observés pour Hylurgops porosus (LeConte), Hylurgops subcostulatus (Mannerheim), Hylastes gracilis (LeConte), Hylastes longicollis (Swaine), Dendroctonus valens (LeConte) et Ips pini (Say). La charge de spores par insecte variait de 0 à plus de $1 \times 10^{5}$ spores, avec seulement quelques insectes transportant plus de $1 \times 10^{3}$ spores. La technique permet de traiter simultanément un grand nombre d'échantillons, comme l'exigent les études épidémiologiques pour étudier le taux d'infection dans les populations de scolytes et identifier les insectes vecteurs potentiels.
\end{abstract}

[Traduit par la Rédaction]

Received 11 May 2004. Accepted 24 March 2005. Published on the NRC Research Press Web site at http://cjrf.nrc.ca on 31 August 2005.

W. Schweigkofler, K. Maeda, K.G. Peay, and M. Garbelotto. ${ }^{1}$ Department of Environmental Science, Policy and Management, 151 Hilgard Hall, University of California, Berkeley, CA 94720, USA.

W.J. Otrosina. USDA Forest Service, Southern Research Station, 320 Green Street, Athens, GA 30602, USA.

S.L. Smith and D.R. Cluck. USDA Forest Service, Pacific Southwest Region, 2550 Riverside Drive, Susanville, CA 96130 , USA.

${ }^{1}$ Corresponding author (e-mail: matteo@nature.berkeley.edu).

\section{Introduction}

Black-stain root disease (BSRD) causes considerable damage in conifer forests in western North America. Symptoms associated with BSRD include reduced growth, chlorosis, dark staining of the tracheids extending from the roots to the lower bole, and ultimately tree death (Jacobs and Wingfield 2001). The causal agent of BSRD is Leptographium wageneri (W.B. Kendr.) M.J. Wingf. (syn. Verticiladiella wageneri W.B. Kendr.), which occurs in three host-specific varieties: $L$. wageneri var. ponderosum infects ponderosa pine (Pinus ponderosa Dougl. ex P. \& C. Laws.), Jeffrey pine (Pinus jeffreyi Grev. \& Balf.), and lodgepole pine (Pinus contorta Dougl. ex Loud.); L. wageneri var. pseudotsugae infects Douglas-fir (Pseudotsuga menziesii (Mirbel) Franco); and $L$. wageneri var. wageneri infects mainly pinyon pine (Pinus monophylla Torr. \& Frem., Pinus edulis Engelm.), although a number of other coniferous hosts have been reported (Jacobs and 
Wingfield 2001). The teleomorph stage of $L$. wageneri var. ponderosum, Ophiostoma wageneri (Goheen \& F.W. Cobb) T.C. Harr. (Harrington 1987), has been isolated only once from ponderosa pine (Goheen and Cobb 1978), and its ecological role remains unknown. No sexual stages of the varieties pseudotsugae and wageneri have been reported.

There appear to be significant differences in the epidemiology and biology of the three host-specific varieties, and not all three are equally understood. For instance, in the Douglas-fir variety, disease severity is related to forest silvicultural practice; for example, young, dense Douglas-fir plantations are much more vulnerable than old-growth stands (Hansen 1997).

In ponderosa pine, short-distance spread of BSRD occurs by root-to-root transmission of the pathogen (Wood et al. 2003). Insect vectors are assumed to play a crucial role in overland spread of fungal inoculum, but experimental evidence is lacking for both the ponderosa and the pinyon varieties of the pathogen. Conidia of Leptographium and related ophiostomatoid fungi are produced in sticky masses (conidial droplets) at the apex of stalked conidiophores, an adaptation for dispersal by insect vectors. Leptographium wageneri is associated with bark beetles (Coleoptera: Scolytidae) such as Dendroctonus spp. (Wagener and Mielke 1961), Hylastes spp. (Goheen 1976), Hylurgops spp. (Wagner 1977), and Ips spp. (Morrison and Hunt 1988). Weevils (Coleoptera: Curculionidae) of the genera Pissodes (Witcosky 1981) and Steremnius (Witcosky 1981) have also been implicated as vectors in Douglas-fir.

Detection of black-stain fungi from infested wood and insect vectors has been carried out traditionally using selective media containing cycloheximide (Harrington 1992; Witcosky 1985). The isolates obtained from the environmental samples have to be purified and then identified morphologically. The procedure is time-consuming and successful isolations of $L$. wageneri from insects are rarely obtained. Isolation of $L$. wageneri var. ponderosum from insects attacking ponderosa pine has never been reported to our knowledge. These problems have severely limited ecological and pathological studies of this insect-disease complex. Recently, molecular detection methods based on genus- and (or) species-specific primers have been developed for a variety of ophiostomatoid strains (Kim et al. 1999), but such tests have not been developed yet for studies on BSRD.

The purpose of this study is (i) to establish a rapid molecular method to detect $L$. wageneri DNA from insects, $(i i)$ to determine the occurrence of $L$. wageneri var. ponderosum on different scolytid bark beetle species in a heavily infected ponderosa pine forest in Northern California, and (iii) to quantify the individual spore load on a given beetle using real-time polymerase chain reaction (PCR).

\section{Materials and methods}

\section{Study site}

The study area $\left(40^{\circ} 39 \mathrm{~N}, 121^{\circ} 12 \mathrm{~W}, 1800 \mathrm{~m}\right.$ elevation), located on the Lassen National Forest, Lassen County, California, has active black-stain root disease centers resulting in current tree mortality. Ponderosa and Jeffrey pines are the predominant tree species with white fir (Abies concolor (Gord. \& Glend) Lindl. ex. Hildebr.) representing less than
$15 \%$ of the basal area; thus infection can be assumed to be exclusively $L$. wageneri var. ponderosum. The approximate age of the pines is 80-100 years, and the average diameter at breast height is $45 \mathrm{~cm}$. Sixteen permanent 3.0 -ha plots, previously established on this location to study effects of silivicultural treatments on disease spread, were utilized in this study to obtain insect samples. Existing black-stain root disease center sizes in these plots ranged from individual infected trees to 0.5 -ha mortality gaps.

\section{Insect sampling}

Bark beetles were collected weekly during the flight period from mid-April to mid-June in 2001 and 2002 . Insects were trapped using 68 Lindgren funnel traps (4-funnels, Phero Tech Inc., Delta, British Columbia) baited with the standard ethanol lure (Phero Tech Inc.) and UHR alpha pinene lure (Phero Tech Inc.) (Lindgren 1983). Trapped insects were stored at $-20{ }^{\circ} \mathrm{C}$ before processing. Insect species were identified based on morphology. To determine phoresy of $L$. wageneri by individual beetle species, one to five specimens belonging to the same species and collected in the same trap were pooled together and screened by PCR as an individual sample. In the case of Hylurgops porosus, the most abundant species, up to 20 specimens from the same trap were pooled together. Length and diameter measurements were taken from 25 specimens of Hylurgops porosus (LeConte), Hylurgops subcostulatus (Mannerheim), Hylastes macer (LeConte), Dendroctonus valens (LeConte), and Ips pini (Say), and from three specimens of Hylastes gracilis (LeConte). Surface area and volume of the beetles were calculated by assuming a cylindrical body shape.

\section{Fungal growth and spore harvest}

Leptographium strains (Table 1) were grown for 8 weeks at $18{ }^{\circ} \mathrm{C}$ on semi-selective medium, which consists of the

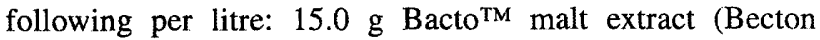
Dickinson, Sparks, Maryland), $1.5 \mathrm{~g} \mathrm{Bacto}^{\mathrm{TM}}$ yeast extract (Becton Dickinson), $15 \mathrm{~g}$ agar (Fisher Scientific, Pittsburgh, Pennsylvania), $0.3 \mathrm{~g}$ streptomycin sulfate (Sigma, St. Louis, Missouri), and $0.2 \mathrm{~g}$ cycloheximide (Sigma). Conidiophores growing on $1.0-\mathrm{cm}^{2}$ agar slices (five replicates) were counted at $15 \times$ magnification using a stereomicroscope (Nikon SMZ 1000). Each agar slice was added to a microtube containing $1 \mathrm{~mL} \mathrm{H}_{2} \mathrm{O}$ and vortexed for $2 \mathrm{~min}$ to dislodge spores. The harvested spores were counted using a hematocytometer (Hausser Scientific, Horsham, Pennsylvania) with a light microscope (Nikon Eclipse E400) and diluted to final concentrations of $1 \times$ $10^{1}-1 \times 10^{6}$ spores $/ \mathrm{mL}$.

\section{Primer design}

The $L$. wageneri specific primer combination LEPTO1 (CAAAGACGGCAGACGCGAGTCTC) and LEPTO2 (GTTCCAGGGAACTCGGAAG) were developed using the primer3 software (www-genome.wi.mit.edu/cgi-bin/primer/ primer3_www.cgi). Primer binding sites were chosen based on the alignment using ClustalX (Thompson et al. 1997) of about $640 \mathrm{bp}$ in the ITS2 and 28SrRNA gene in the nuclear ribosomal region of 44 Leptographium and Ophiostoma strains (Jacobs et al. 2001) (Fig. 1). Because DNA sequences at the primer binding sites for the ITS 2 and $28 \mathrm{~S}$ loci are identical across all three varieties of $L$. wageneri, the 
Table 1. Amplification of a 230-bp polymerase chain reaction (PCR) fragment in the ITS2-28SrRNA region from ophiostomatoid (Leptographium and Ophiostoma) and nonophiostomatoid pathogens of conifers.

\begin{tabular}{|c|c|c|c|c|}
\hline Species & Strain & Collection $^{a}$ & Origin & $\begin{array}{l}\text { PCR } \\
\text { amplification }\end{array}$ \\
\hline \multirow[t]{14}{*}{ L. wageneri var. ponderosum } & ATCC 58574 & ATCC & B.C., Canada & + \\
\hline & $\mathrm{BCL}-2$ & UC Berkeley & B.C., Canada & + \\
\hline & BCL-3 & UC Berkeley & B.C., Canada & + \\
\hline & CAP-A & UC Berkeley & Calif., USA & + \\
\hline & CAP-4 & UC Berkeley & Calif., USA & + \\
\hline & CAP-3b 12 & UC Berkeley & Calif., USA & + \\
\hline & CAJ -4 & UC Berkeley & Calif., USA & + \\
\hline & $\mathrm{CAJ}-1$ & UC Berkeley & Calif., USA & + \\
\hline & LEPTO-5 & UC Berkeley & Calif., USA & + \\
\hline & CAP-5 & UC Berkeley & Calif., USA & + \\
\hline & IDP-1 & UC Berkeley & Idaho, USA & + \\
\hline & ORP-1 & UC Berkeley & Ore., USA & + \\
\hline & MOD-22 & UC Berkeley & Mo., USA & + \\
\hline & NMD-1 & UC Berkeley & N.M.,USA & + \\
\hline \multirow[t]{2}{*}{ L. wageneri var. wageneri } & CAS-1 & UC Berkeley & Calif., USA & + \\
\hline & NME-1 & UC Berkeley & N.M.,USA & + \\
\hline L. neomexicanum & L 41 & TC Harrington & N.M.,USA & + \\
\hline L. reconditum & ATCC 36819 & ATCC & South Africa & + \\
\hline L. serpens & L 153 & TC Harrington & Mo., USA & + \\
\hline L. abietinum & ATCC 62324 & ATCC & B.C., Canada & - \\
\hline L. albopini & L 155 & TC Harrington & Colo., USA & - \\
\hline L. lundbergii & ATCC 62325 & ATCC & Canada & - \\
\hline L. procerum & ATCC 58100 & ATCC & New Zealand & - \\
\hline L. terebrantis & L 20 & T.C. Harrington & Calif., USA & - \\
\hline O. clavigerum & L 841 & T.C. Harrington & Calif., USA & - \\
\hline O. huntii & L 88 & T.C. Harrington & B.C., Canada & - \\
\hline O. ips & L 1307 & T.C. Harrington & Iowa, USA & - \\
\hline O. piceaperdum & ATCC 16058 & ATCC & Wash., USA & - \\
\hline Fusarium circinatum & NRRL 25331 & UC Berkeley & Ga., USA & - \\
\hline Heterobasidion annosum & C 6 & UC Berkeley & Calif., USA & - \\
\hline Phytophthora ramorum & $\operatorname{Pr} 217$ & UC Berkeley & Calif., USA & - \\
\hline
\end{tabular}

${ }^{a}$ ATCC, American Type Culture Collection, Rockville, Md.; UC Berkeley, University of California, Berkeley. T.C. Harrington, Department of Natural Resource Ecology and Management, Iowa State University.

primers are specific to the species complex rather than one variety. However, because the pathogen varieties are host specific and do not co-occur in our study area, this is unlikely to be problematic in our or other study sites. The amplicon size was 230 bp. Primers were synthesized by Qiagen-Operon Inc., Alameda, California. Specificity of the primers was tested by running PCR reactions on 16 isolates of $L$. wageneri from across the pathogen's range as well as on 15 other Leptographium and forest pathogens (Table 1).

\section{DNA extraction and PCR amplification}

DNA from fungal colonies grown on selective medium was extracted using a "hyphal tipping" method: mycelium was scraped from the Petri dish and suspended in $100 \mu \mathrm{L}$ of distilled water, frozen on dry ice for $3 \mathrm{~min}$, thawed at $75^{\circ} \mathrm{C}$, and vortexed for $2 \mathrm{~min}$. Freezing and thawing was repeated three times, with the last thaw extended to $15 \mathrm{~min}$. Samples were spun down for $5 \mathrm{~min}$ at $15700 \mathrm{~g}$, and $6.25 \mu \mathrm{L}$ of the supernatant was used for PCR reactions.
Suspensions of varying concentrations of fungal spores were employed to develop reference standards for DNA-based quantification of spore loads found on insects. Fungal spore suspensions and bark beetles were added to a microtube and mechanically disrupted by shaking with $6.35 \mathrm{~mm}$ diameter glass beads for $30 \mathrm{~s}$ using an amalgamator (BIO 101, Carlsbad, California). After adding $0.3 \mathrm{~mL}$ of $2 \%$ CTAB (cetyltrimethylammonium bromide), the samples were subjected to three freeze-thaw cycles $\left(2 \mathrm{~min}\right.$ on dry ice, $2 \mathrm{~min}$ at $75^{\circ} \mathrm{C}$, repeated three times with the last thaw extended to $30 \mathrm{~min}$ ). DNA was extracted using $0.35 \mathrm{~mL}$ phenol - chloroform isoamyl alcohol followed by purification using the Geneclean kit (BIO 101), following instructions by the manufacturer.

The PCR mix consisted of $8.0 \mu \mathrm{L} \mathrm{H}_{2} \mathrm{O}, 2.5 \mu \mathrm{L}$ PCR buffer (Promega, Madison, Michigan), $5.0 \mu \mathrm{L} \mathrm{MgCl}_{2}(25 \mathrm{mmol} / \mathrm{L}$, Promega), $2.5 \mu \mathrm{L}$ dNTP ( $2 \mathrm{mmol} / \mathrm{L}$, Promega), $0.25 \mu \mathrm{L}$ primer LEPTO1 $(50 \mathrm{mmol} / \mathrm{L}), 0.25 \mu \mathrm{L}$ primer LEPTO2 $(50 \mathrm{mmol} / \mathrm{L})$, $0.25 \mu \mathrm{L} \mathrm{Taq}$ polymerase (Promega), and $6.25 \mu \mathrm{L}$ DNA template. The cycling profile was denaturation at $94.0^{\circ} \mathrm{C}$ for 
Fig. 1. Primer binding sites for the primers LEPTO1 and LEPTO2 were chosen based on an alignment of about 640 bp in the ITS2 and 28SrRNA gene in the nuclear ribosomal region of 44 Leptographium and Ophiostoma strains from Jacobs and Wingfield (2001). Here we show alignment of the $L$. wageneri specific primer LEPTO1 (underlined) in the ITS2 region with closely related species from Clade III of Wingfield and Jacobs (2001) as well as L. neomexicanus and L. serpens. There is little variation in the LEPTO2 priming site in the 28SrRNA, so the alignment is not shown. The strains used for alignment from the Jacobs and Wingfield study are $L$. abietinum (AF343669.1), L. abietinum (AF343670.1), O. trinacriforme (AF343671.1), L. douglasii (AF343672.1), O. crassivaginatum (AF343673.1), L. pineti (AF343674.1), L. elegans (AF343675.1), L. brachiatum (AF343676.1), L. antibioticum (AF343677.1), O. brevicolle (AF343678.1), L. pityophilum (AF343679.1), L. abietinum (AF343680.1), O. abiocarpum (AF343681.1), O. huntii (AF343682.1), L. guttulatum (AF343683.1), L. wingfieldii (AF343684.1), L. alethinum (AF343685.1), L. euphyes (AF343686.1), O. americanum (AF343687.1), O. americanum (AF343688.1), L. pyrinum (AF343689.1), L. reconditum (AF343690.1), O. laricis (AF343691.1), L. procerum (AF343692.1), O. europhioides (AF343693.1), O. piceaperdum (AF343694.1), L. albopini (AF343695.1), L. albopini (AF343696.1), L. lundbergii (AF343697.1), L. terebrantis (AF343698.1), O. aureum (AF343699.1), L. hughesii (AF343700.1), L. abicolens (AF343701.1), O. francke-grosmanniae (AF343702.1), L. eucalyptophilum (AF343703.1), O. penicillatum (AF343704.1), O. robustum (AF343705.1), L. wageneri var. pseudostugae (AF343706.1), L. wageneri var. wageneri (AF343707.1), L. wageneri var. ponderosum (AF343708.1), O. dryocoetidis (AF343709.1), O. leptographioides (AF343710.1), O. grandifoliae (AF343711.1), L. costaricense (AF343712.1).
L. pityophilum
GC: :TG :CC TGC :GC CCT GCC TAT CA: GAC GC: AAG TCT ATC :TC A:A AGG
O. leptographioides
o. grandifoliae
o. robustum :AC AAG ::A CGC GGG GGG GCC CGC CG: CCC CC: CCT CCC TTC :TC GCA AGG GCC CTG :CC CGC AGC GAG AGC TG: CG: AAC AC: CC: CCC TT: :TT ACA AGG
o. crassivaginatum
L. reconditum
o. serpens
L. Iundbergii
L. albopini
o. aureum
o. piceaperdum
o. europhioides
o. Laricis
I. procerum
L. terebrantis
L. neomexicanum
L. wageneri G:C CTG :CC CGC AGC GAG AGC TG: CG: AAC AC: CC: CCC TT: :TT ACA AGG GCC CTG CCC C:: AGA :C: AGC AGA CGC AAG TC: T:A CCC TTT TTC ACA AGG GCC CTG CCC CAA AGA :C: GGC AGA CGC GAG TC: T:: CCC TCC TTC TCA AGG GCC CTG CCC CAA AGA :C: GGC AGA CGC GAG TC: T:: CCC TCC TTC TCA AGG GCC CTG CCC CCC AGA CC: GGC AGA CGC GAG TC: T: : GCC CCC TTC TCA AGG GCC CT: CCC CCC AGA CC: GGC AGA CGC GAG TC: T:: GCC TCC TTC TCA AGG GCC CTG CCC CAC AGA CC: GGC AGA CGC GAG TC: T: : GCC TCC TTC TCA AGG GCC CTG CCC TTA TT: TTT GGC AGA CGT AAG TC: TG: :CC TCC TTC TAA AGG GCC CTG CCC CTA :T: TCT GGC AGA CGT AAG TC: TG: :CC TCC TTC TCA AGG GCC TTG CCC CCA :T: TTT GGC AGA CGT AAG TC: TG: :CC TCC TTC TCA AGG GCC CTG CCC CAA ATG ACC GGC AGA CGC AAG TCT TGC CCC TCC TTC TCA AGG GCC CTG CCC CAA ATG ACC GGC AGA CGC AAG TC: TGC CCC TCC TTC TCA AGG GCC CTG CCC CAA AGA :C: GGC AGA CGC GAG TC: T:: CCC TCC TTC TCA AGG GCC CTG CCC CAA AGA :C: GGC AGA CGC GAG TC: T:: CCC TCC TTC TCA AGG

$180 \mathrm{~s}$, followed by 45 cycles of $94{ }^{\circ} \mathrm{C}$ for $35 \mathrm{~s}, 65^{\circ} \mathrm{C}$ for $55 \mathrm{~s}, 72{ }^{\circ} \mathrm{C}$ for $50 \mathrm{~s}$, then final extension at $72{ }^{\circ} \mathrm{C}$ for $10 \mathrm{~min}$. PCR products were checked on a $1.5 \%$ agarose gel and stained with ethidium bromide. Negative $\mathrm{PCR}$ reactions were checked for failed DNA extraction using the universal primers ITS1 and ITS4 (White et al. 1990).

\section{Real-time PCR amplification for the quantification of fungal spores}

Spore suspensions from $L$. wageneri var. ponderosum (ATCC 58574) diluted in $\mathrm{H}_{2} \mathrm{O}$ to final concentrations of $1 \times$ $10^{1}-1 \times 10^{6}$ spores $/ \mathrm{mL}$ were used to establish standard curves. Real-time PCR using SYBR ${ }^{\circledR}$ Green I (Applied Biosystems, Foster City, California) was performed on an iCycler (Bio-Rad, Hercules, California). To quantify the starting amount of template DNA, the threshold cycle $(\mathrm{Ct})$ for each sample was calculated. The $\mathrm{Ct}$ value, which is the cycle number when a significant increase of SYBR Green fluorescence is first recorded against the background fluorescence level, was calculated using baseline cycles 2 to 10 . The $\mathrm{Ct}$ value is proportional to the logarithm of the initial DNA concentration. The data analysis window was set at $10.00 \%$ of a cycle and centered at the end of the cycle. Reaction conditions for real-time PCR were $7.5 \mu \mathrm{L} \mathrm{H}_{2} \mathrm{O}$, $2.5 \mu \mathrm{L}$ PCR buffer, $5.0 \mu \mathrm{L} \mathrm{MgCl}_{2}(25 \mathrm{mmol} / \mathrm{L}), 2.5 \mu \mathrm{L}$
$\mathrm{dNTP}, 0.25 \mu \mathrm{L}$ primer LEPTO1 $(50 \mathrm{mmol} / \mathrm{L}), 0.25 \mu \mathrm{L}$ primer LEPTO2 (50 mmol/L), $1.25 \mu \mathrm{L}$ SYBR Green, $1.25 \mu \mathrm{L}$ fluorescein (Bio-Rad, Hercules, California), $0.25 \mu \mathrm{L}$ Taq polymerase, and $6.25 \mu \mathrm{L}$ DNA template. Cycling parameters were $94.0^{\circ} \mathrm{C}$ for $180 \mathrm{~s}$, followed by 45 cycles of $94{ }^{\circ} \mathrm{C}$ for $35 \mathrm{~s}, 62^{\circ} \mathrm{C}$ for $55 \mathrm{~s}, 72^{\circ} \mathrm{C}$ for $50 \mathrm{~s}$, and a final extension at $72{ }^{\circ} \mathrm{C}$ for $10 \mathrm{~min}$. Melting curves were measured for 110 cycles of $10 \mathrm{~s}$ each, starting at $62^{\circ} \mathrm{C}$ and increasing by $0.3{ }^{\circ} \mathrm{C}$ each cycle. Melt-curve peaks can be displayed graphically as $\mathrm{d}$ (relative fluorescence units)/d $t$ versus temperature. The temperature at which dsDNA fragments are completely denatured into single strands is dependent not only on the size of the fragments, but also on their guaninecytosine content. Melt-curve analysis is thus more powerful than gel electrophoresis and can be used to verify specificity of PCR amplicons (Hayden et al. 2004).

To test the possible inhibitory effects of beetle DNA on quantification of $L$. wageneri spore, loads spore standards were spiked with extracted DNA from PCR negative beetles. These were run alongside clean reactions containing the same spore standard to compare threshold cycles for signs of inhibition. Reactions were carried out using identical real-time PCR protocols (see above) except that $6.25 \mu \mathrm{L}$ of beetle DNA extract was added to the spiked standard in lieu of an equal volume of $\mathrm{H}_{2} \mathrm{O}$ in the reaction. Multiple replicates were performed for all spore concentrations for each of the four 
Table 2. Detection of Leptographium DNA from bark beetles (Coleoptera: Scolytidae) sampled in 2001 and 2002 in the Lassen National Forest, California.

\begin{tabular}{|c|c|c|c|c|c|c|}
\hline \multirow[b]{2}{*}{ Bark beetle species } & \multicolumn{3}{|c|}{ Beetle sampling } & \multicolumn{3}{|c|}{ Detection of $L$. wageneri } \\
\hline & $\begin{array}{l}\text { No. of } \\
\text { bark beetles }\end{array}$ & $\begin{array}{l}\text { No. of } \\
\text { samples taken }\end{array}$ & $\begin{array}{l}\% \text { traps with } \\
\text { beetles (of } 68 \text { ) }\end{array}$ & $\begin{array}{l}\text { No. of } \\
\text { PCR+ samples }\end{array}$ & $\begin{array}{l}\% \text { PCR+ } \\
\text { traps (of 68) }\end{array}$ & $\begin{array}{l}\% \text { PCR+ } \\
\text { samples }\end{array}$ \\
\hline \multicolumn{7}{|l|}{2001} \\
\hline Total (8 species) & 662 & $250^{b}$ & - & $91^{b}$ & 83.8 & 36.4 \\
\hline Dendroctonus valens & 55 & 38 & 55.9 & 9 & 13.2 & 23.7 \\
\hline Hylastes gracilis & 18 & 14 & 20.1 & 3 & 4.4 & 21.4 \\
\hline Hylurgops longicollis & 3 & 3 & 4.4 & 1 & 1.5 & 33.3 \\
\hline Hylastes macer & 59 & 41 & 60.3 & 26 & 38.2 & 63.4 \\
\hline Hylurgops porosus & 318 & 68 & 100 & 22 & 32.4 & 32.4 \\
\hline Hylurgops reticulatus & 1 & 1 & 1.5 & 1 & 1.5 & 100 \\
\hline Hylurgops subcostulatus & 168 & 63 & 92.6 & 27 & 39.7 & 42.9 \\
\hline Ips pini & 40 & 22 & 32.4 & 2 & 2.9 & 9.1 \\
\hline \multicolumn{7}{|l|}{2002} \\
\hline Total (5 species) & 246 & $134^{b}$ & - & $51^{b}$ & 52.9 & 38.1 \\
\hline Dendroctonus valens & 25 & 15 & 22.1 & 3 & 4.4 & 20 \\
\hline Hylastes macer & 29 & 20 & 29.4 & 15 & 22.1 & 75 \\
\hline Hylastes tenuis & 2 & 2 & 2.9 & 0 & 0 & 0 \\
\hline Hylurgops porosus & 149 & 66 & 97.1 & 19 & 27.9 & 28.8 \\
\hline Hylurgops subcostulatus & 41 & 31 & 45.6 & 14 & 20.6 & 45.2 \\
\hline Grand total ( 9 species) & 908 & $384^{b}$ & - & $142^{b}$ & 89.7 & 37 \\
\hline
\end{tabular}

beetle species that were collected in traps both years $(D$. valens, Hylurgops subcostulatus, Hylastes macer, Hylurgops porosus).

The quantification parameters described herein were used to perform quantitative PCR reactions on individual beetles that had resulted positive for $L$. wageneri using the standard PCR assay. Quantification of fungal spores was not attempted for samples consisting of pooled insects.

\section{Sequence analyses}

Regular PCR products were cleaned via QiaQuick PCR Purification kit (Qiagen Sciences, Valencia, California), as per kit instructions, except that cleaned products were eluted in $30 \mu \mathrm{L}$ salt-free water. Cleaned products were cycle sequenced with $4 \mu \mathrm{L}$ BigDye Terminator version 3.0 (Applied Biosystems (ABI)), 2.4 pmol salt-free primer, and 5-20 ng DNA (template concentration determined by gel). Cycle sequencing was performed on an iCycler (Bio-Rad) according to ABIrecommended protocol: 26 cycles of $96^{\circ} \mathrm{C}$ for $10 \mathrm{~s}, 55^{\circ} \mathrm{C}$ for $5 \mathrm{~s}, 60{ }^{\circ} \mathrm{C}$ for $4 \mathrm{~min}$, followed by a hold at $4{ }^{\circ} \mathrm{C}$. Samples were desalted in ethanol as per ABI instructions $(80 \mu \mathrm{L} 60 \%$ ethanol, spun to precipitate at $2500 \mathrm{~g}$ for $30 \mathrm{~min}$, supernatant discarded, then samples brought up to $150 \mu \mathrm{L}$ in $70 \%$ ethanol and spun at $2500 \mathrm{~g}$ for $10 \mathrm{~min}$, supernatant discarded and dried by a slow inverted spin at $500 \mathrm{~g}$ for $30 \mathrm{~s}$ ) (ABI Prism 3100 Genetic Analyzer Sequencing Chemistry Guide). Samples were brought up in $10 \mu \mathrm{L} \mathrm{Hi-Di} \mathrm{Formamide} \mathrm{(ABI)} \mathrm{and}$ denatured on a thermocycler $\left(95^{\circ} \mathrm{C}\right.$ for $5 \mathrm{~min}$, followed by a hold at $4{ }^{\circ} \mathrm{C}$ ). Capillary electrophoresis was performed on an ABI Prism 3100 Genetic Analyzer, with a POP-4 polymer on a $36-\mathrm{cm}$ capillary array. Data were collected on Data Col- lection Software version 1.0 and analyzed on Sequencher ${ }^{\mathrm{TM}}$ version 3.0 (Gene Codes Corporation, Ann Arbor, Michigan).

\section{Results}

\section{Insect sampling}

Bark beetles were collected weekly from all traps during both sampling seasons (Table 2). Overall insect captures were considerably higher in 2001 (250 samples) than in 2002 (134 samples). Four species were collected in both years: Hylurgops porosus was the most prevalent species in both years, followed by Hylurgops subcostulatus, Hylastes macer, and $D$. valens (Table 2). Low numbers of I. pini, Hylastes gracilis, Hylastes longicollis, and Hylurgops reticulatus (Wood) were collected only in 2001. Hylastes tenuis (Eichhoff) was collected from two traps only in 2002.

\section{Primer specificity}

The primers LEPTO1 and LEPTO2 amplified a single PCR product of $230 \mathrm{bp}$ from genomic DNA in all 16 isolates of $L$. wageneri tested, including all three varieties of the pathogen (Table 1). The primers did not amplify most other Leptographium and Ophiostoma strains tested, with the exception of Leptographium neomexicanum, Leptographium reconditum, and Leptographium serpens.

\section{Detection of Leptographium DNA from naturally infected bark beetles using regular PCR}

A total of 384 insect samples (for a total of 908 insect specimens) were analyzed for the presence of Leptographium DNA using the primers LEPTO1 and LEPTO2 (Table 2). An 
Fig. 2. Polymerase chain reaction amplification of a 230-bp DNA fragment using the primers LEPTO1 and LEPTO2 from fungal colonies (lanes 3-9) and bark beetles (lanes 13-23). Lane 1, 100-bp DNA ladder (Promega); 2, water negative control; 3, L. wageneri; 4, L. reconditum; 5, O. piceaperdum; 6, L. abietinum; 7, L. lundbergii; 8, L. procerum; 9 , L. terebrantis; 10 , water negative control; 11, DNA ladder; 12, water negative control; 13, DNA extracted from Hylurgops porosus (20 beetles pooled); 14, DNA extracted from Hylurgops porosus (10 beetles pooled); 15, DNA extracted from Hylurgops porosus (five beetles pooled); 16, DNA extracted from Hylurgops porosus (one beetle); 17, DNA extracted from Hylastes macer (one beetle); 18, DNA extracted from Hylurgops subcostulatus (one beetle); 19, DNA extracted from Dendroctonus valens (one beetle); 20, DNA extracted from Hylurgops porosus (one beetle); 21, DNA extracted from Hylastes macer (one beetle); 22, DNA extracted from Hylurgops subcostulatus (one beetle); 23, DNA extracted from $D$. valens (one beetle); 24, water negative control; 25, DNA ladder.

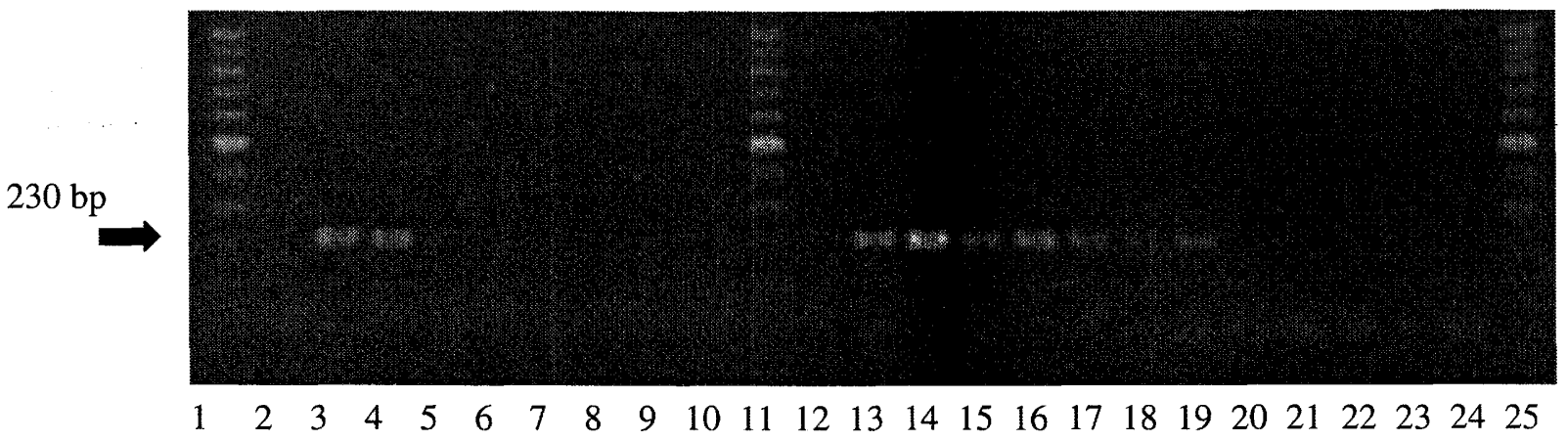

initial set of experiments was carried out using Hylurgops porosus, the most abundant bark beetle species, to test for the lowest number of insects from which fungal DNA could be detected. The 230-bp $L$. wageneri DNA fragment was amplified regularly from tubes were DNA extractions were carried out on $20,10,5$, and even single individual insects (Fig. 2). For the other experiments, one to five insects were pooled and processed in a single tube. A PCR product was obtained from 91 of 250 samples (36.4\%) collected in 2001. In 2002,134 samples were collected, with 51 showing a positive PCR amplification (38.1\%). PCR positives were not found among bark beetles collected from seven traps $(10.3 \%)$. All PCR negatives using LEPTO1 and LEPTO2 were successfully amplified using the universal primers ITS1 and ITS4.

\section{Identity of the PCR fragments}

Specificity of all products was verified by analyses of melt curves. Representative PCR fragments obtained from each insect species (two per species) and from each tester L. wageneri var. ponderosum isolate (Table 1) were sequenced and compared with the GenBank using BLAST search. All samples showed a $100 \%$ identity with the published sequence of $L$. wageneri var. ponderosum.

\section{Number of fungal spores and conidiophores on selective medium}

The number of conidiophores and spores produced by reference strains of $L$. wageneri var. ponderosum (Table 1) was counted after 8 weeks of growth on selective medium. On average, 143-202 conidiophores were counted per square centimetre $\left(\right.$ mean $\left.=169 / \mathrm{cm}^{2}\right)$. The number of spores ranged between $1.13 \times 10^{7}$ and $2.40 \times 10^{7}$ conidiospores $/ \mathrm{cm}^{2}$ (mean $=$ $1.85 \times 10^{7}$ ). This would correspond to approximately. $0.70 \times$ $10^{5}-1.38 \times 10^{5}$ conidiospores per conidiophore (mean $=$ $1.10 \times 10^{5}$ spores per conidiophore). The diameter of a single conidial droplet was approximately $100 \mu \mathrm{m}$.

\section{Quantification of fungal spores using real-time PCR}

The calibration curve for DNA extracted from $L$. wageneri spores is shown in Fig. 3 (three replicates). Threshold cycles (Ct) were negatively correlated with the number of spores in the range from $1 \times 10^{2}$ to $1 \times 10^{6}$ spores $/ \mathrm{mL}$. When a spore concentration of $1 \times 10^{1}$ spores $/ \mathrm{mL}$ was used, a PCR fragment was still amplified and detected on the agarose gel, but the threshold cycles became inconsistent (data not shown). The 230-bp PCR fragment showed a sharp melt peak at $89.5^{\circ} \mathrm{C}\left( \pm 1.0^{\circ} \mathrm{C}\right)$, which was clearly distinguishable from the flattened peaks produced by primer dimers at about $82.0^{\circ} \mathrm{C}$ (data not shown).

At spore concentrations $>1 \times 10^{3}$, there was no significant difference between clean and spiked standards (one-tailed paired sample $t$ test, $t=1.21,34 \mathrm{df}, p=0.12$ ). At spore concentrations $\leq 1 \times 10^{3}$ L. wageneri var. ponderosum DNA could be amplified in spiked samples, but its quantification was unreliable. In $89 \%$ of 44 reactions, in fact, PCR resulted in amplicons characterized by the exact expected size and meltcurve profile for $L$. wageneri, but threshold cycles were often too low or unscorable for quantitative purposes. The effect of beetle species on standard threshold cycles was not significant in a one-way ANOVA $\left(F_{[3,42]}=0.8767, p=0.46\right)$.

Only PCR-positive insect samples consisting of a single specimen were used for the quantitative analysis with realtime PCR. DNA quantification was thus performed for a total of 44 samples from 2001 and 27 samples from 2002. The number of Leptographium spores carried by single bark beetles was inferred from the comparative analysis between DNA amounts found in suspensions of known spore concentration and DNA amounts in the tested insect samples (Fig. 4). To be conservative in accounting for effects of beetle DNA on quantification we grouped samples with $\leq 1 \times 10^{3}$ spores in one category. Spore loads within a given species varied across five orders of magnitude. All species contained a relatively high number of specimens without detectable spores. The lowest detectable spore load was estimated to be 10 1000 spores per insect. The highest estimates of the number 
Fig. 3. Standard curves for quantifying $L$. wageneri DNA using real-time polymerase chain reaction with SYBR Green ${ }^{\circledR}$ as the fluorescent dye. Threshold cycles $(\mathrm{Ct})$, corresponding to the increase of template DNA above background level, were plotted against the $\log$ of genomic DNA extracted from spore suspensions in the range from $1 \times 10^{2}$ to $1 \times 10^{6}$ spores $/ 100 \mu \mathrm{L}$.

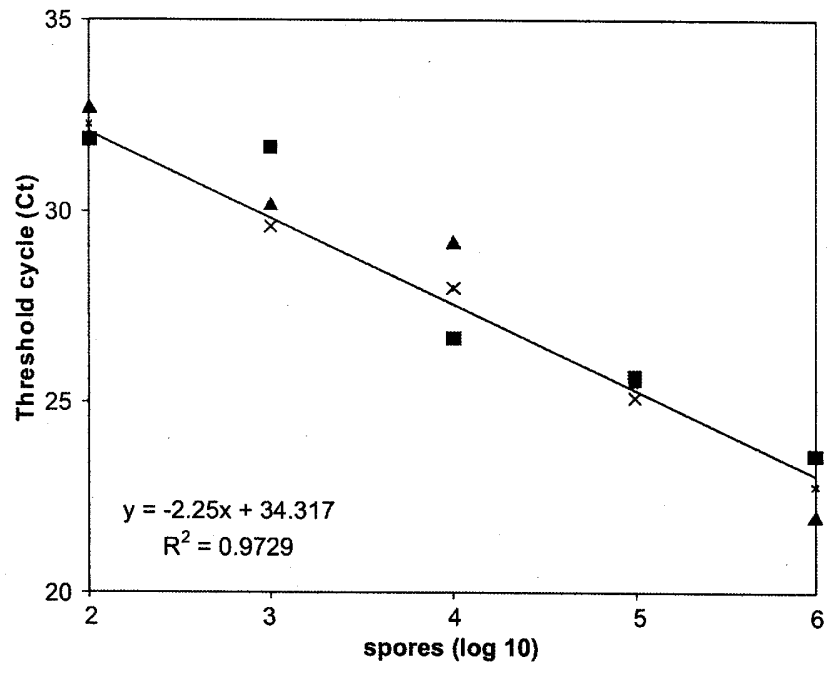

of spores were in the range of $1 \times 10^{5}$ to $1 \times 10^{6}$ spores per individual beetle. However, this high association rate was found only for two specimens of Hylastes macer (2001 and 2002) and for one specimen of each Hylurgops subcostulatus (2002) and Hylastes gracilis (2001). In most cases, the number of spores per individual beetle was in the range of $1 \times$ $10^{1}$ to $1 \times 10^{4}$. In both years total spore load was highest for Hylastes macer.

\section{Correlation between detected amounts of $L$. wageneri DNA and size of beetles}

The surface area of individual adult bark beetles varied greatly among the different species, with $D$. valens being the largest, followed by the medium-sized species Hylastes macer, Hylurgops porosus, and Hylurgops subcostulatus, and the smallest species $I$. pini and Hylastes gracilis (Table 3 ). The relative size of these three beetle groups corresponded roughly to $7: 2: 1$. The bark beetle most often associated with fungal DNA, Hylastes macer, was the second largest of these species. The two other species of similar size, Hylurgops porosus and Hylurgops subcostulatus, showed an intermediate association with $L$. wageneri DNA. Dendroctonus valens, on the other hand, was the species among the four captured in both 2001 and 2002 with the lowest association rate with fungal DNA. The association rate with fungal DNA for Hylastes gracilis was very similar to that for $D$. valens. Ipis pini, the smallest of all bark beetles, had the lowest association rate.

\section{Discussion}

Previous evidence regarding the role played by insects in the epidemiology of BSRD

Vectoring of fungal inoculum by bark beetles is thought to play a crucial role in the epidemiology of BSRD (Hansen
1997; Wood et al. 2003). Detection and quantification of $L$. wageneri by incubating dead bark beetles on artificial media is complicated by its slow growth, causing inhibition and overgrowth by faster growing filamentous fungi, yeasts, and other ophiostomatoid species (Zhou et al. 2001), even when cycloheximide is added to the medium (W. Schweigkofler, unpublished data). Witcosky (1985) presented low association rates of Verticiladiella wageneri (=L. wageneri) with beetles in Douglas-fir stands in Oregon where the fungus was isolated from less than $5 \%$ of 668 Hylastes nigrinus, Steremnius carinatus, and Pissodes fasciatus beetles. Even given the limited success in isolating this fungus from Douglas-fir associated bark beetles, processing large numbers of insect samples can be very timeconsuming and laborious. Rapid detection of ophiostomatoid fungi from infected wood using PCR was reported previously (Kim et al. 1999), but to our knowledge molecular techniques have not been used yet for the detection of Leptographium from associated insects in ponderosa pine.

\section{Species detected by method described and potential for cross-reactivity}

The primers LEPTO1 and LEPTO2 amplified a fragment from $L$. wageneri and $L$. reconditum as was expected based on published sequence information (Jacobs et al. 2001). No sequences were available previously for $L$. neomexicanum and $L$. serpens, which have an identical primer binding site based on our results and newly available sequence data (Fig. 1). However, geographic distribution and (or) host range of these species differ widely from those of $L$. wageneri. Leptographium reconditum was isolated exclusively from the rhizosphere of monocots (Triticum spp. and Zea mays) in South Africa, and no association with insects is known (Jooste 1978). Also $L$. neomexicanum is not known to be vectored by bark beetles and has only been reported from New Mexico (Jacobs and Wingfield 2001). Leptographium serpens occurs mainly in Europe and South Africa, with very few observations from North America (Jacobs and Wingfield 2001). On the other hand, primers LEPTO1 and LEPTO2 do not amplify DNA of Leptographium terebrantis, a pathogenic species that is widespread in western North America, attacks a wide range of conifers (e.g., $P$. ponderosa), and is associated with several bark beetle species (Jacobs and Wingfield 2001). To further confirm the identity of the PCR fragments, we sequenced representative samples from every bark beetle species and found them to be identical with published $L$. wageneri sequences.

Leptographium wageneri occurs in three varieties that are distinguishable mainly by host specificity. In addition, isozyme analysis (Otrosina and Cobb 1987; Zambino and Harrington 1992) and DNA fingerprinting using random amplified polymorphic DNA - PCR (Witthuhn et al. 1997) showed differences among the varieties. Minor morphological differences are also present but difficult to observe for nonspecialists. Although our study focused exclusively on the single variety known to infect $P$. ponderosa, the ribosomal gene region we used for developing the primers LEPTO1 and LEPTO2 is identical for the three varieties (Jacobs et al. 2001). We conclude therefore that the molecular marker used in the present study is well suited for ecological studies on the association 
Fig. 4. Quantification of Leptographium spores from bark beetles using real-time polymerase chain reaction. Hylastes macer (a), Hylurgops porosus (b), Hylurgops subcostulatus (c), and Dendroctonus valens (d) were collected both in 2001 (black bars) and 2002 (grey bars). Ipis pini, Hylastes gracilis, Hylastes longicollis, and Hylastes reticulatus (three beetles) were collected only in 2001.
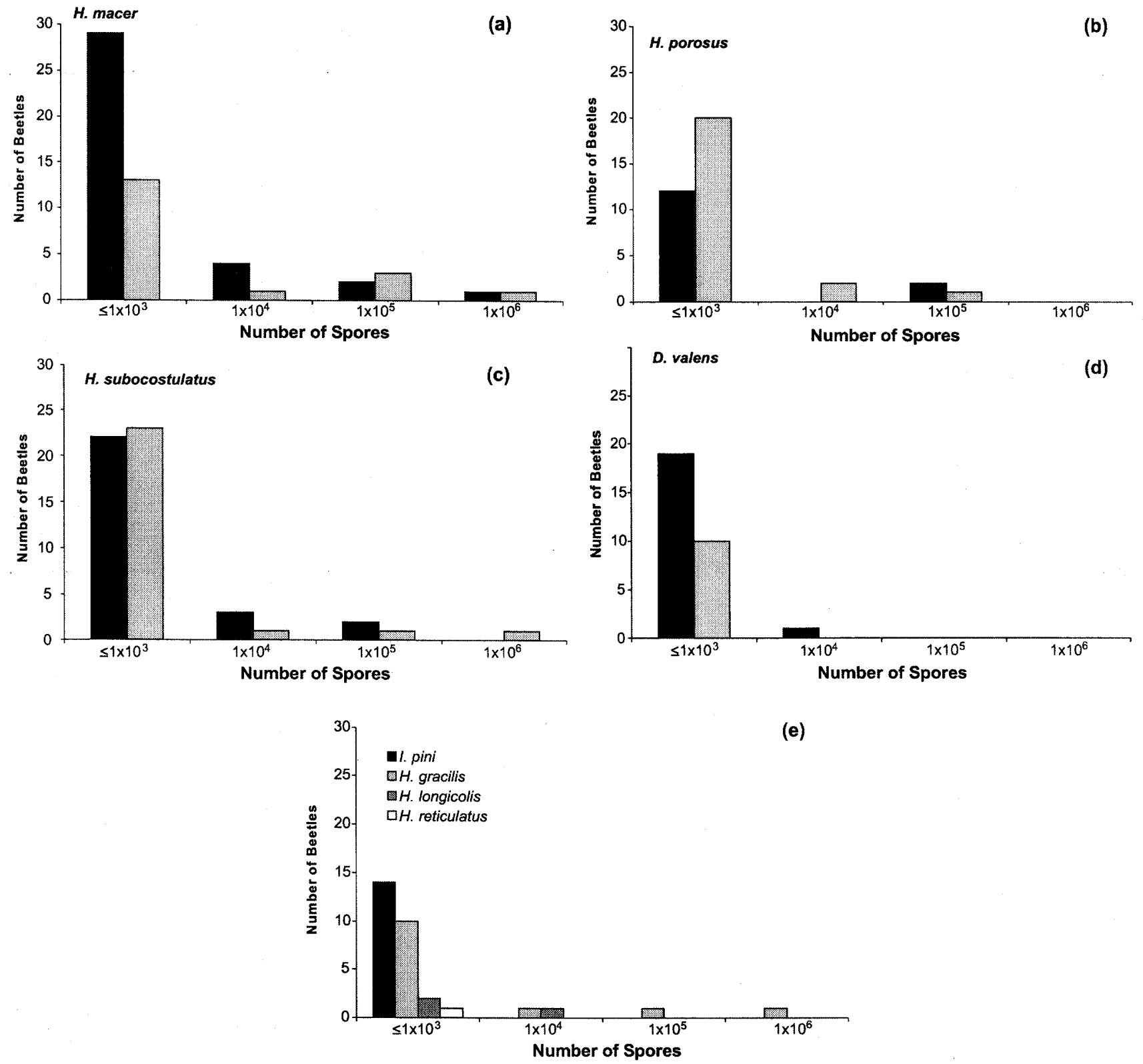

between all three varieties of the black stain pathogen $L$. wageneri and associated bark beetles.

Insects trapped in our study: differences and similarities amongst them

Of the nine bark beetle species we collected, only four species (Hylurgops porosus, Hylurgops subcostulatus, Hylastes macer, and D. valens) were sampled in both 2001 and 2002. Extreme fluctuations of bark beetle densities are well known and can reach up to four orders of magnitude within 5 years
(Turchin et al. 1991; Reeve et al. 1995). The bark beetles Hylastes gracilis, Hylastes longicollis, and Hylastes macer infest a range of pine species in the western United States, among them ponderosa pine, sugar pine (Pinus lambertiana Dougl.), Jeffrey pine, and lodgepole pine (Wood et al. 2003). The broods develop under the bark of the root crown and in the roots of dying and dead trees, in stumps and in the underside of logs, and in slash in contact with the ground (Furniss and Carolin 1977; Wood 1982). Hylurgops spp. also attack the phloem of the root collar, the main roots of 
Table 3. Size of bark beetle species used for the detection of Leptographium DNA.

\begin{tabular}{lllcl}
\hline Species $^{a}$ & Length $(\mathrm{mm})$ & Diameter $(\mathrm{mm})$ & Volume $\left(\mathrm{mm}^{3}\right)$ & Surface $\left(\mathrm{mm}^{2}\right)$ \\
\hline Dendroctonus valens & $7.68 \pm 1.38$ & $3.1 \pm 0.9$ & $52.1 \pm 14.3$ & $84.5 \pm 16.7$ \\
Hylastes gracilis & $4.0 \pm 0.0$ & $1.0^{b}$ & $3.1 \pm 0.0$ & $14.1 \pm 0.0$ \\
Hylastes macer & $5.78 \pm 0.72$ & $1.5^{b}$ & $10.2 \pm 1.4$ & $30.8 \pm 3.7$ \\
Hylurgops porosus & $4.98 \pm 1.02$ & $1.5^{b}$ & $8.8 \pm 1.8$ & $27.0 \pm 4.8$ \\
Hylurgops subcostulatus & $4.28 \pm 0.72$ & $1.5^{b}$ & $7.6 \pm 1.2$ & $23.7 \pm 3.4$ \\
Ips pini & $2.88 \pm 0.38$ & $1.0^{b}$ & $2.3 \pm 0.7$ & $10.6 \pm 2.7$ \\
\hline
\end{tabular}

Note: Values are means \pm standard deviations

"Twenty-five specimens were measured for each species (Hylastes gracilis: three specimens)

${ }^{b}$ Standard deviations were not determined for the diameters of the very small and uniform bark beetle species:

dying or dead trees, or freshly cut stumps (Furniss and Carolin 1977; Wood 1982). In western North America, they can be found on most pine species and some fir species.

Dendroctonus valens is the largest and most widely distributed bark beetle in North America and has been reported from more than 40 conifer species. Vertical galleries are excavated in the phloem of the lower trunk and to a lesser extent in larger roots (Wood et al. 2003). This species usually attacks trees of reduced vigor or those infested with other bark beetles, but it also can attack apparently healthy trees (Smith 1971).

Ipis pini attacks many conifers, including ponderosa, Jeffrey, and lodgepole pines. This beetle species infests mainly saplings and pole-sized trees, logging slash, windthrown trees, or trees broken by wind or snow (Kegley et al. 1997). Females construct tunnels or "egg galleries" in the phloem layer, slightly scoring the wood surface in the process. Reports on the ecology of Hylastes tenuis and Hylurgops reticulatus are scant (Hanula et al. 1998; Kelsey and Joseph 2003; Miller et al. 1986).

The bark beetle Hylastes nigrinus (Mannerheim) and the weevils Pissodes fasciatus (LeConte) and Steremnius carinatus (Boheman) (Coleoptera: Curculionidae) were shown to carry L. wageneri inoculum in Douglas-fir stands in the Pacific Northwest (Witcosky and Hansen 1985) and to transmit L. wageneri to seedlings under laboratory conditions (Witcosky 1985) but were not collected in our study.

\section{Mitotic spores as the main inoculum for BSRD}

Sexual recombination and the development of ascospores are known to play a crucial role in the epidemiology of other ophiostomatoid fungi, e.g., Ophiostoma novo-ulmi, the causal agent of Dutch elm disease (Brasier 2001). In the case of $L$. wageneri var. ponderosum, a sexual stage $(=O$. wageneri) was detected only once from ponderosa pines (Goheen and Cobb 1978). Sexual recombination may be a rare event in this pathogen (Otrosina and Cobb 1987), and we assume that the inoculum carried by the bark beetle consists predominantly of asexual conidia.

Contamination of insects with fungal spores could occur when different species of bark beetles are captured in the same trap. This could theoretically be the case for $D$. valens, I. pini, Hylastes gracilis, and Hylastes longicollis, which were found to be less often associated with $L$. wageneri DNA than were Hylurgops porosus, Hylurgops subcostulatus, and Hylastes macer. However, at least one sample of each of the former four species was found to carry $L$. wageneri DNA when no other PCR-positive insect sample was present in the same trap. This indicates that cross-contamination in the trap from other insects is unlikely.

Inoculum phoresy determined first by ecology of insect species and second by size of insect

The presumed physical attachment of $L$. wageneri spores to the exoskeleton of bark beetles could suggest a correlation between the size of the beetles and the number of spores they carry. Our study shows that some insect genera are more effective carriers than others (e.g., Hylastes > Hylurgops $>$ Dendroctonus $>$ Ips), independently of insect size; for example, $D$. valens, the largest species, showed only a low association with $L$. wageneri DNA. The insect species from which $L$. wageneri DNA was found most consistently (Hylastes macer, Hylurgops porosus, and Hylurgops subcostulatus) are of intermediate size. In the Dutch elm disease pathosystem, low inoculum numbers of $O$. novo-ulmi were isolated from the two smaller bark beetle species Scolytus kirschi and Scolytus multistratus, whereas the larger beetle Scolytus scolytus was associated with a higher number of fungal spores (Webber et al. 1987; Webber 1990, 2000).

It is not surprising that different insect species may vary in their ability to carry inoculum. Differential niche colonization and reproductive strategies may be one of the factors explaining such variations among groups of insects. For instance, the location of the pupal chamber is of crucial importance for the amount of fungal inoculum per bark beetle (Webber 2000). Because of the total removal of surface tissue during insect metamorphosis, conidia that were attached to the larvae will not be present at the surface of the imago. Consequently, all fungal spores carried by the vector must attach to the imago during emergence from the pupal chamber to the bark surface. Therefore, beetles pupating in inner bark chambers of the lower trunk or in roots (e.g., Hylastes macer) are more likely to carry a high spore load than beetles pupating in the outer bark.

Quantification of spore loads and putative classification of insects as carriers based on spore load

In the Dutch elm disease pathosystem, Webber (1990) estimated the spore load for $S$. scolytus to be in the range of 1 to 350000 spores per beetle, for $S$. multistratus 1 to 30000 spores, and $S$. kirschi had less than 300 spores per beetle. Scolytus scolytus is similar in size to Hylastes macer (mean length: $5.4 \pm 0.3 \mathrm{~mm}$; Webber 1990); the size of $S$. kirschi $(2.5 \pm 0.3 \mathrm{~mm})$ corresponds roughly to that of $I$. pini. Our 
quantification of L. wageneri spores using real-time PCR resulted in similar estimates of the number of spores (Fig. 4). For example, we detected between 0 to several hundred thousand spores on Hylastes macer, Hylurgops subcostulatus, and Hylastes gracilis, but only a few specimens yielded more than 10000 spores. On average, the spore load on single beetles was highest for Hylastes macer in both years. Hylurgops porosus was associated with only a moderate number of spores, but could still contribute significantly to $L$. wageneri inoculum dispersal because of high insect numbers in both years. The number of spores on $D$. valens and $I$. pini was, with the exception of a single $D$. valens individual, below 1000. This is consistent with their known ecological niche, making them unlikely to vector $L$. wageneri var. ponderosum.

In the case of $O$. novo-ulmi, a minimum of $1 \times 10^{3}$ conidia is required for infection of Ulmus procera. Infection was not always assured even with an inoculum load of $5 \times$ $10^{4}$ conidia (Webber 1987; Webber and Gibbs 1989). If a similar inoculum threshold would be necessary for the infection of ponderosa pines with $L$. wageneri, then only a small percentage of the insects in our study would act as effective vectors. A single conidiophore of $L$. wageneri contains, on average, ca. $1 \times 10^{5}$ conidia in a slimy droplet. In pure culture up to $200 / \mathrm{cm}^{2}$ conidial droplets were produced. Therefore it is highly probable that a beetle may touch more than one droplet when emerging from its pupal chamber to the tree surface. However, not all conidia will stick to the exoskeleton, and some might be lost during the flight of the beetle to new hosts (e.g., because of UV inactivation).

Our results substantiate the hypothesis that Hylastes macer might be the most important vector for the longdistance dispersal of $L$. wageneri, although other root feeding bark beetle species such as Hylurgops porosus might be involved in the disease cycle. The DNA techniques we report provide a new tool to study the epidemiology of black-stain root disease. Understanding the interactions among inoculum potential, beetle ecology, host tree physiology, and site edaphic factors as they relate to disease susceptibility and severity is crucial to minimizing disease impact.

\section{Acknowledgements}

We thank Tom Harrington, Iowa State University, for the kind gift of Leptographium and Ophiostoma strains, and Amy Smith for her technical assistance. This work was supported by Technology Improvement grant by US Forest Service Southwestern Region (Region 5) and Special Technology Development Funds and Forest Health Protection Funds from the USDA Forest Service.

\section{References}

Brasier, C.M. 2001. Rapid evolution of introduced plant pathogens via interspecific hybridization. Bioscience, 51: 123-133.

Furniss, R.L., and Carolin, V.M. 1977. Western forest insects. USDA For. Serv. Misc. Publ. 1339.

Goheen, D.J. 1976. Verticiladiella wageneri on Pinus ponderosa: epidemiology and interrelationships with insects. Ph.D. thesis, University of California, Berkeley, Calif.
Goheen, D.J., and Cobb, F.W. 1978. Occurrence of Verticiladiella wageneri and its perfect state, Ceratocystis wageneri sp. nov., in insect galleries. Phytopathology, 68: 1192-1195.

Hansen, E. 1997. Leptographium diseases. In Compendium of conifer diseases. Edited by E.M. Hansen and K.L. Lewis. APS Press, St. Paul, Minn. pp. 8-9.

Hanula, J.L., Meeker, J.R., Miller, D.R., and Barnard, E.L. 1998. The effects of the 1998 Florida wildfires on pine bark beetles, reproduction weevils, and their associates. USDA For. Serv. Study Plan FS-SRS-4505-34.

Harrington, T.C. 1987. New combinations in Ophiostoma of Ceratocystis species with Leptographium anamorphs. Mycotaxon, 28: $39-43$.

Harrington, T.C. 1992. Leptographium. In Methods for research on soilborne phytopathogenic fungi. Edited by L.L. Singleton, J.D. Mihail, and C.M. Rush. APS Press, St. Paul, Minn. pp. 129133.

Hayden, KJ., Rizzo, D., Tse, J., and Garbelotto, M. 2004. Detection and quantification of Phytophthora ramorum from California forests using a real-time polymerase chain reaction assay. Phytopathology, 94: 1075-1083.

Jacobs, K., and Wingfield, M.J. 2001. Leptographium species. Tree pathogens, insect associates and agents of blue stain. APS Press, St. Paul, Minn.

Jacobs, K., Wingfield, M.J., and Wingfield, B.D. 2001. Phylogenetic relationships in Leptographium based in morphological and molecular characters. Can. J. Bot. 79: 719-732.

Jooste, W.J. 1978. Leptographium reconditum sp. nov., and observations on conidiogenesis in Verticiladiella. Trans. Br. Mycol. Soc. 70: 152-155.

Kegley, S.J., Livingston, R.L., and Gibson, K.E. 1997. Pine engraver, Ips pini (Say), in the Western United States. USDA For. Serv. For. Pest Leafl. 122.

Kelsey, R.G., and Joseph, G. 2003. Ethanol in ponderosa pine as an indicator of physiological injury from fire and its relationship to secondary beetles. Can. J. For. Res. 33: 870-884.

Kim, S.H., Uzunovic, A., and Breuil, C. 1999. Rapid detection of Ophiostoma picea and $O$. quercus in stained wood by PCR. Appl. Environ. Microbiol. 65: 287-290.

Lindgren, B.S. 1983. A multiple funnel trap for scolytid beetles (Coleoptera). Can. Entomol. 115: 299-302.

Miller, D.R., Madden, J.L., and Borden, J.H. 1986. Primary attraction of Ips latidens (LeConte) and Hylastes gracilis LeConte (Coleoptera: Scolytidae) to high-girdled lodgepole pine Pinus contorta var. latifolia Engelmann. Can. Entomol. 118: 85-88.

Morrison, D.J., and Hunt, R.S. 1988. Leptographium species associated with root disease of conifers in British Columbia. In Leptographium root diseases on conifers. Edited by T.C. Harrington and F.W. Cobb, Jr. APS Press, St. Paul, Minn. pp. 97112.

Otrosina, W.J., and Cobb, F.W., Jr. 1987. Analysis of allozymes of three distinct variants of Verticicladiella wageneri isolated from conifers in western North America. Phytopathology, 77: 13601363.

Reeve, J.R., Ayres, M.P., and Lorio, P.L. 1995. Host suitability, predation, and bark beetle population dynamics. In Population dynamics: new approaches and synthesis. Edited by N. Cappuccino and P. Price. Academic Press, Burlington, Mass. pp. 339357.

Smith, R.H. 1971. Red turpentine beetle. USDA For. Serv. For. Pest Leafl. 55.

Thompson, J.D., Gibson, T.J., Plewniak, F., Jeanmougin, F., and Higgins, D.G. 1997. The ClustalX windows interface: flexible 
strategies for multiple sequence alignment aided by quality analysis tools. Nucleic Acids Res. 24: 4876-4882.

Turchin, P., Lorio, P.L., Taylor, A.D., and Billings, R.F. 1991. Why do populations of southern pine beetles (Coleoptera: Scolytidae) fluctuate? Environ. Entomol. 20: 401-409.

Wagener, W.W., and Mielke, J.L. 1961. A staining fungus root disease of ponderosa, Jeffrey and pinyon pines. Plant Dis. Rep. 45: 831-835.

Wagner, R.E. 1977. Verticiladiella species associated with Hylurgops porosus LeConte (Coleoptera: Scolytidae) in lodgepole pine. M.Sc. thesis. University of Idaho, Moscow, Idaho.

Webber, J.F. 1987. Influence of the $\mathrm{d}^{2}$ factor on survival and infection by the Dutch elm disease pathogen Ophiostoma ulmi. Plant. Pathol. 36: 531-538.

Webber, J.F. 1990. Relative effectiveness of Scolytus scolytus, Scolytus multistriatus and Scolytus kirschi as vectors of Dutch elm disease. Eur. J. For. Pathol. 20: 184-192.

Webber, J.F. 2000. Insect vector behavior and the evolution of Dutch elm disease. In The elms: breeding, conservation, and disease management. Edited by C.P. Dunn. Kluwer Academic Publisher, Boston, Mass. pp. 47-60.

Webber, J.F., and Gibbs, J.N. 1989. Insect dissemination of fungal pathogens of trees. In Insect-fungus interactions. Edited by N. Wilding, N.M. Collins, P.M. Hammond, and J.F. Webber. Academic Press, Oxford, UK. pp. 161-193.

Webber, J.F., Brasier, C.M., and Mitchell, A.D. 1987. The role of the saprophytic phase in Dutch elm disease. In Plant infecting fungi. Edited by G.F. Pegg and P.G. Ayers. Cambridge University Press, Cambridge, UK. pp. 298-314.

White, T.J., Bruns, T.D., Lee, S., and Taylor, J.W. 1990. Amplification and direct sequencing of fungal ribosomal RNA genes for phylogenetics. In PCR protocols: a guide to methods and appli- cations. Edited by M.A. Innis, D.H. Gelfand, J.J. Sninsky, and T.J. White. Academic Press, Inc., New York. pp. 315-322.

Witcosky, J.J. 1981. Insects associated with black-stain root disease of Douglas-fir in western Oregon. M.Sc. thesis, Oregon State University, Corvallis, Ore.

Witcosky, J.J. 1985. The root insect-black-stain root disease association in Douglas-fir: vector relationships and implications for forest management. Ph.D. thesis, Oregon State University, Corvallis, Ore.

Witcosky, J.J., and Hansen, E.M. 1985. Root-colonizing insects associated with Douglas-fir in various stages of decline due to black-stain root disease. Phytopathology, 75: 399-402.

Witthuhn, R.C., Wingfield, B.D., Wingfield, M.J., and Harrington, T.C. 1997. Comparison of three varieties of Leptographium wageneri using Random Amplified Polymorphic DNA. S. Afr. J. Bot. 63: 198-200.

Wood, S.L. 1982. The bark and ambrosia beetles of North and Central America (Coleoptera: Scolytidae): a taxonomic monograph. Great Basin Nat. Mem. 6.

Wood, D.L., Koerber, T.W., Scharpf, R.F., and Storer, A.J. 2003. Pests of the native California conifers. University of California Press, Berkeley, Calif.

Zambino, P.J., and Harrington, T.C. 1992. Correspondence of isozyme characterization with morphology in the asexual genus Leptographium and taxonomic implications. Mycologia, 84: 1225.

Zhou, X.D., de Beer, Z.W., Wingfield, B.D., and Wingfield, M.J. 2001. Ophiostomatoid fungi associated with three pine-infesting bark beetles in South Africa. Sydowia, 53: 290-300. 